\title{
Relationships between portable chlorophyll meter estimates for the red mangrove tree (Rhizophora mangle L.)
}

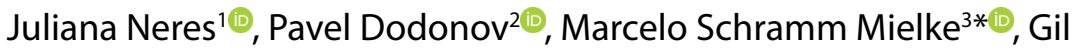 \\ Marcelo Reus Strenzel ${ }^{4}$ (1)
}

\begin{abstract}
1 Universidade Estadual de Santa Cruz, Programa de Pós-graduação em Sistemas Aquáticos Tropicais - Campus Soane Nazaré de Andrade, km 16, Rodovia Ilhéus-Itabuna - 45662-900 - Ilhéus-BA - Brazil

${ }^{2}$ Universidade Federal da Bahia, Instituto de Biologia - Rua Barão de Jeremoabo, 668 - Campus de Ondina - 40170-115 - Salvador - BA - Brazil

${ }^{3}$ Universidade Estadual de Santa Cruz, Departamento de Ciências Biológicas - Campus Soane Nazaré de Andrade, Rodovia Jorge Amado, km 16, Bairro Salobrinho - 45662-900 - Ilhéus - Bahia - Brazil

${ }^{4}$ Universidade Estadual de Santa Cruz, Departamento de Ciências Agrárias e Ambientais - Campus Soane Nazaré de Andrade, Rodovia Jorge Amado, km 16, Bairro Salobrinho - 45662-900 - Ilhéus - Bahia - Brazil

*Corresponding author: msmielke@uesc.br
\end{abstract}

Several ecosystem processes and services provided by mangrove trees, such as the regulation of biogeochemical cycles, biological control, soil retention and protection against erosion, and especially $\mathrm{CO} 2$ assimilation and carbon storage are related to the photosynthetic process (Donato et al. 2011; Schaeffer-Novelli et al., 2016; Santos et al., 2017). Photosynthesis is directly related to chlorophyll present in the leaves, and assessment of chlorophyll concentrations may be used as an indicator of a plants' physiological condition. Decreases in leaf chlorophyll concentrations occur in plants exposed to environmental stress, including stress caused by heavy metals (Chandra \& Kang, 2016), nutrient deficiency (Kalaji et al., 2017), and petroleum pollution (Arellano et al., 2017), among others. Thus, estimates of chlorophyll concentrations may provide information on plant and ecosystem function (Heenkenda et al., 2015; Pastor-Guzman et al., 2015).

Chlorophyll concentrations can be quantified by destructive or non-destructive methods, on scales ranging from a single leaf to the entire ecosystem. Non-destructive quantification of chlorophyll in single leaves is performed with

Submitted on: $24 /$ January/2020

Approved on: $16 /$ July/2020

Associate Editor: Camila Signori

Editor: Rubens M. Lopes

(i) 2020 The authors. This is an open access article distributed under the terms of the Creative Commons license. portable chlorophyll measurement devices, which estimate the chlorophyll concentrations in leaves by quantifying the incident radiation that is absorbed by the chlorophyll molecules (Parry et al., 2014; PastorGuzman et al., 2015; Vieira Silva et al., 2016). The chlorophyll concentration in an ecosystem may be assessed indirectly with remote sensing techniques (Heenkenda et al., 2015; Pastor-Guzman et al., 2015). The quick and non-destructive measurement of photosynthetic pigments via portable chlorophyll meters may optimize the sampling effort and the cost of data collection in the field.

Currently, there are different portable chlorophyll meters available, and the most commonly used of these are the SPAD-502 (Minolta, Osaka, Japan), the CCM-200 (OptiSciences, Tyngsboro, Massachusetts, USA), and the Clorofilog (Falker, Porto Alegre, Brazil). The first two devices, the SPAD-502 and the CCM200 provide total chlorophyll indices based on two wavelengths, namely 650 and $940 \mathrm{~nm}$ (SPAD-502) and 660 and $940 \mathrm{~nm}$ (CCM-200), in the red and nearinfrared bands (Parry et al., 2014; Richardson et al., 2002). However, the Clorofilog chlorophyll meter uses three wavelengths $(635,660$, and $880 \mathrm{~nm})$ to provide estimates of concentrations of chlorophyll a, chlorophyll b, and total chlorophyll $(a+b)$ (Vieira Silva et al., 2016). Electric signals are received by analogical receptors, which calculate chlorophyll absorbance in the red band and differentiate the leaves' internal structure in the near-infrared band, indirectly obtaining the chlorophyll indices (Markwell 
et al., 1995). Portable chlorophyll meters provide estimates in dimensionless units, and mathematical models are required to express the leaves' real pigment values. However, mathematical models lack for many species. For instance, few mathematical models have been developed for mangrove trees (Biber, 2007; Connelly, 1997; Flores-de-Santiago et al., 2013). Care must be taken when using mathematical models that have been developed for a different device and species than that being used and studied, as, even though the different devices have similar functions, they still need to be calibrated for each device and plant species (Richardson et al., 2002; Parry et al., 2014). When mathematical models have been developed for at least one type of chlorophyll meter, they may be used to calibrate other devices. Thus, calibrations between the SPAD-502 and the CCM200 have already been performed to test the devices' efficiency (Richardson et al., 2002). This fact has been achieved by correlating the chlorophyll indices provided by the two devices. These correlations have shown that devices may be calibrated indirectly (without destructive measurements), by converting the chlorophyll indices between each device.

The most common genera in the Brazilian mangroves are Rhizophora (Rhizophoraceae), Laguncularia (Combretaceae), and Avicennia (Acanthaceae) (Schaeffer-Novelli et al., 1990; Magris \& Barreto, 2010). The red mangrove, R. mangle, is an essential mangrove species and occurs in many countries, including Brazil. It has support roots and a root system that eliminates a large part of the salt present in the water and is considered a facultative halophyte (Rebelo-Mochel et al., 2007; Medeiros et al., 2018). Mathematical models relating chlorophyll indices measured using portable chlorophyll meters and chlorophyll concentrations for red mangroves have been developed for the SPAD-502 (Connelly, 1997) and the CCM-200 (Biber, 2007; Flores-deSantiago et al., 2013). There are no models that can be used to measure chlorophyll concentrations in other Neotropical mangrove species using the SPAD-502. Besides, recent studies have used the Clorofilog to estimate chlorophyll indices in mangrove trees (Lopes et al., 2019; Orto e Silva et al., 2020), despite the absence of mathematical models that allow estimation of actual leaf chlorophyll concentrations. As the SPAD-502 is one of the most commonly used chlorophyll meters and as Connelly's (1997) model has already been tested (e.g., Pastor-Guzman et al., 2015), it is possible to develop a mathematical model that can be used to measure leaf chlorophyll concentrations using the Clorofilog without destructive measurements, by relating the values obtained with the Clorofilog to those provided by the SPAD-502. In this study, we propose and validate a mathematical model for converting Clorofilog chlorophyll estimates into the more common and already validated SPAD-502 values for red mangroves.

This study was performed in a mangrove area in the municipality of Ilhéus, southern Bahia State, Brazil (14.82o S, 39.06oW). The studied mangrove is of the riverine type, located along the Engenho river, which is part of the largest estuarine complex in the region, alongside the Cachoeira and Fundão rivers. The regional climate is wet tropical, without a defined dry season (Af in Köppen's classification) (Sparovek et al., 2007). The area includes native vegetation, urban areas, and domestic waste released along with the entire river extension, resulting in anthropogenic stress that may affect the mangrove's ecological balance and ecosystem services (Martins et al., 2011). Plant material was collected at nine sampling points along the Engenho river. The sampling points were accessed using a motorboat, and their location was recorded with a hand-held GPS device (GPSMap 64s - Garmin). Red mangrove leaves were collected with an extendable pruner, and only leaves under direct sun exposure were collected. We randomly selected four to five branches in trees next to the mangrove's edge, which could belong to the same or different individuals. These branches were placed in plastic bags, which were labeled with the sampling point's coordinates. The leaves were stored in a cooler box on ice and transported to the Plant Physiology lab of Universidade Estadual de Santa Cruz (Ilhéus, Bahia, Brazil). Even though the chlorophyll meters evaluated in our study can be used in the field, we chose to make the lab measurements for logistical reasons and avoid damage to the equipment. However, these devices are appropriate for field measurements when taking the leaves to the lab is not possible. We collected approximately 30 leaves at each sampling point; however, some leaves were later observed to belong to a different species and had to be excluded from the analysis. After transporting the samples to 
the lab, young leaves were removed, and 241 fully mature and expanded red mangrove leaves, with a yellow-green to dark green color, were analyzed.

We used the portable chlorophyll meters SPAD-502 and Clorofilog CFL1030 to estimate the chlorophyll indices and to perform calibrations among the devices. The portable chlorophyll meter SPAD-502 uses the SPADi index, whereas the Clorofilog provides estimates in the Falker chlorophyll index $(\mathrm{FCl})$. For each leaf, we performed a single measurement with the SPAD-502 and the Clorofilog, with measurements taken at the same location on the median region of the leaf's adaxial side, next to the central nervure.

Before the analyses, three outliers were removed. We, therefore, had a total of 238 data points for each device. We used paired t-tests to test whether the two devices provided different estimates $(p<0.05)$. For the predictive model to transform Clorofilog $\mathrm{FCl}$ values into SPADi index values, we first divided it into calibration and a validation dataset, with 119 leaves in each. We then adjusted a linear regression based on the calibration dataset, with the $\mathrm{FCl}$ values as the explanatory variable and the SPADi values as the response variable. We visually assessed residual normality and homoscedasticity of this analysis. Finally, we applied the resultant equation to the validation dataset and calculated Pearson's correlation coefficient $(p<0.05)$ between the observed values and the estimated values. We assessed the quality of our mathematical model by visually analyzing the model's residuals for normality, residual patterns, and outliers. The data were analyzed in R 3.5.1 (R Core Team, 2018) and in the software Past 3.1 (Hammer et al., 2001).

The SPADi values ranged from 34.40 to 71.40 (mean of $55.05 \pm 7.63 \mathrm{SD} ; \mathrm{CV}=13.86 \%$ ) and the $\mathrm{FCl}$ values ranged from 28.60 and 65.90 (mean of $49.42 \pm 7.63 ;$ CV of $14.45 \%)$. On average, the SPADi values were $5.64 \pm 0.24 \mathrm{SE}$ units higher than the $\mathrm{FCl}$ values for the same leaf (permutation t-test: $\mathrm{t}=$ 22.63, $p=2.2 * 10-71)$. The regression analysis of the SPADi values and the $\mathrm{FCl}$ values showed a strong linear relationship between the two instruments $(R=$ $\left.0.92, \mathrm{p}<2.2^{*} 10-16\right)$, described by the model SPADi $=10.0595+0.9092 * \mathrm{FCl}$ (Figure 1a). The validation analysis showed a strong relationship $(R=0.92, p<$
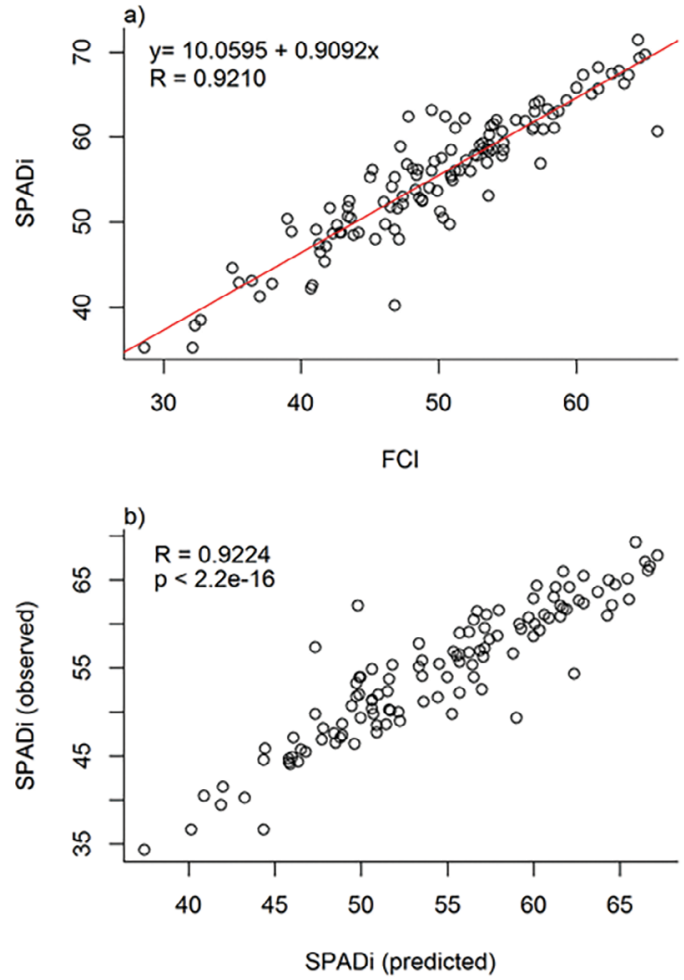

Figure 1. Relationship between SPADi and Falker chlorophyll index $(\mathrm{FCl})$ estimates of chlorophyll indices for red mangroves. Each point represents one leaf $(n=119)$ (a). Validation of the model for converting $\mathrm{FCl}$ values into SPADi values for red mangroves. Each point represents one leaf $(n=119)(b)$.

$\left.2.2^{*} 10-16\right)$ between the SPADi values predicted by this model and the observed values (Figure $1 \mathrm{~b}$ ).

The two devices provided different estimates for chlorophyll concentrations in red mangrove leaves, with the SPAD-502 providing higher values than the Clorofilog. The wavelengths used by the different devices to obtain chlorophyll indices vary, and are an essential factor in obtaining these indices for different species. This difference may be related to the wavelengths used to measure chlorophyll absorbance. A previous study has shown that the SPAD-502 estimated higher values than the CCM-200 portable chlorophyll meter for Citrus sp. Leaves (Jifon et al., 2005). Also, the SPAD-502 may have a smaller measurement error than the CCM-200 (Richardson et al., 2002). Nevertheless, some studies have observed small differences in the indices estimated by the SPAD-502 and by the Clorofilog (Brito et al., 2011; 
Vieira Silva et al., 2016), indicating that it is possible to adjust these indices between the devices.

One factor that may have led to the relatively low $R$ values between the two chlorophyll meters used in our study compared to other studies comparing different devices (Richardson et al., 2002; Brito et al., 2011; Parry et al., 2014; Vieira Silva et al., 2016) may be associated with the way the measurements were made. There is a possibility that the overlap between the areas on the leaf surface where the two measurements were made was imperfect. The SPADi values were less variable than the $\mathrm{FCl}$ values, as previously observed (Brito et al., 2011; Vieira Silva et al., 2016). Besides, there was much variation around the adjusted line. As there were few yellow-green leaves compared to the number of green leaves being analyzed, the points were more concentrated in the center of the distribution, possibly affecting the curve's adjustment.

Despite the $16 \%$ variation in the relationship between the two devices, we were able to compute a calibration curve that resulted in a reasonably high correlation between the observed and the estimated values in the validation dataset $(R=0.92)$. Similar relations between different chlorophyll meters have been observed in previous studies (Brito et al., 2011; Vieira Silva et al., 2016). Thus, our model for transforming $\mathrm{FCl}$ values into SPADi values may be used in future studies on chlorophyll concentrations in red mangroves. However, as chlorophyll values vary among species and their environments, we do not recommend the use of this equation for other species, and instead recommend species-specific equations for each new plant species in which chlorophyll concentrations are measured (Jifon et al., 2005; Zhang et al., 2012). The differences between the two indices, as observed here, highlight the importance of performing such calibrations (Richardson et al., 2002).

The in-situ measurement of chlorophyll indices concentrations with the aid of portable chlorophyll meters permits researchers to preserve plant material, optimize fieldwork, and reduce costs associated with reagents, and this last factor applies even if the measurements are taken in the lab and not in the field. In this study, we developed a mathematical model to convert chlorophyll values between two portable chlorophyll meters, the Clorofilog and the SPAD-502.
As the Clorofilog is a portable device that operates similarly to the SPAD-502 (Brito et al., 2011; Vieira Silva et al., 2016), and has been used increasingly frequently, this comparison will enable betweenstudy comparison and encourage future studies using the Clorofilog. A more detailed calibration curve maybe by including a more extensive range of chlorophyll concentrations. Similar models can be developed for other mangrove species.

In conclusion, we demonstrated that the chlorophyll concentration indices calculated by the SPAD-502 and by the Clorofilog for red mangrove, an important mangrove species, can be converted between one another. However, this calibration is not perfect, as there was still a $16 \%$ unexplained variation in the comparison between the two devices. Thus, care must be taken when converting measurements and when comparing results obtained with different chlorophyll meters, as between-device variation may introduce noise into the analyses, and hamper the detection of biological or ecological patterns.

\section{ACKNOWLEDGEMENTS}

This study was financed in part by the Coordenação de Aperfeiçoamento de Pessoal de Nível Superior - Brasil (CAPES) - Finance Code 001, via a master's scholarship to the first author. The authors gratefully acknowledge Amanda Freitas Cerqueira and Igor Pires Reis for helping with data collection in the field and laboratory, the llhéus marina, and the pilot Alberto for field assistance. We also thank Dr. Fábio Pinto Gomes for providing the SPAD-502 used in this study. Marcelo S. Mielke gratefully acknowledge CNPq (Brazilian National Council for Scientific and Technological Development) for the award of fellowship of scientific productivity (305477/2018-8). We would like to thank Editage (www.editage.com) for English language editing.

\section{AUTHOR CONTRIBUTIONS}

J.N.N.: Conceptualization; Formal Analysis; Investigation; Writing - original draft; Writing review \& editing; P.D.: Formal Analysis; Writing - review \& editing; G.M.R.S.: Supervision; Writing - original draft; Writing - review \& editing; M.S.M.: Conceptualization; Investigation; Writing original draft; Writing - review \& editing. 


\section{REFERENCES}

ARELLANO, P., TANSEY, K., BALZTER, H., TELLKAMP, M. 2017. Plant family-specific impacts of petroleum pollution on biodiversity and leaf chlorophyll content in the Amazon Rainforest of Ecuador. PloS One, 12, e0169867.

BIBER, P. D. 2007. Evaluating a chlorophyll content meter on three coastal wetland plant species. Journal of Agricultural, Food and Environmental Sciences, 1, 1-11.

BRITO, G. G., SOFIATTI, V., BRANDÃO, Z. N., SILVA, V. B., SILVA, F. M. \& SILVA, D. A. 2011. Non-destructive analysis of photosynthetic pigments in cotton plants. Acta Scientiarum. Agronomy, 33, 671-678.

CHANDRA, R., KANG, H. 2016. Mixed heavy metal stress on photosynthesis, transpiration rate, and chlorophyll content in poplar hybrids. Forest Science and Technology, 12, 55-61.

CONNELLY, X. M. 1997. The Use of a chlorophyll meter (SPAD-502) for field determinations of red mangrove (Rhizophora mangle L.) leaf chlorophyll amount. NASA Univ. Res. Cent. Tech. Adv. Educ. Aeronaut. Space Auton. Earth Environ, 1, 187-190.

DONATO, D. C., KAUFFMAN, J. B., MURDIYARSO, D., KURNIANTO, S., STIDHAM, M. \& KANNINEN, M. 2011. Mangroves among the most carbon-rich forests in the tropics. Nature geoscience, 4, 293-297.

FLORES-DE-SANTIAGO, F., KOVACS, J. M. \& FLORES-VERDUGO, F. 2013. Assessing the utility of a portable pocket instrument for estimating seasonal mangrove leaf chlorophyll contents. Bulletin of Marine Science, 89, 621-633.

HAMMER, Ø., HARPER, D. A., \& RYAN, P.D. 2001.PAST:Paleontological statistics software package for education and data analysis. Palaeontologia electronica, version 3.1. Oslo, Noruega.

HEENKENDA, M. K., JOYCE, K. E., MAIER, S. W. \& BRUIN, S. 2015. Quantifying mangrove chlorophyll from high spatial resolution imagery. ISPRS Journal of Photogrammetry and Remote Sensing, 108, 234-244.

JIFON, J. L., SYVERTSEN, J. P. \& WHALEY, E. 2005. Growth environment and leaf anatomy affect nondestructive estimates of chlorophyll and nitrogen in Citrus sp. leaves. Journal of the American Society for Horticultural Science, 130, 152-158.

KALAJI, H. M., DABROWSKI, P., CETNER, M. D., SAMBORSKA, I. A., LUKASIK, I., BRESTIC, M., ZIVCAK, M., TOMASZ, H., MOJSKI, J., KOCIEL, H., PANCHAL, B. M. 2017. A comparison between different chlorophyll content meters under nutrient deficiency conditions. Journal of Plant Nutrition, 40, 10241034.

LOPES, D. M. S., TOGNELLA, M. M. P., FALQUETO, A. R., SOARES, M. L. G. 2019. Salinity variation effects on photosynthetic responses of the mangrove species Rhizophora mangle L. growing in natural habitats. Photosynthetica, 57, 11421155.

MAGRIS, R. A. \& BARRETO, R. 2010. Mapping and assessment of protection of mangrove habitats in Brazil. Pan-American Journal of Aquatic Sciences, 5(4), 546-556.

MARKWELL, J., OSTERMAN, J. C. \& MITCHELL, J. L. 1995. Calibration of the Minolta SPAD-502 leaf chlorophyll meter. Photosynthesis research, 46, 467-472.
MARTINS, P. T. A., COUTO, E.C. G. \& DELABIE, J. H. C. 2011. Fitossociologia e estrutura vegetal do manguezal do rio Cururupe (Ilhéus, Bahia, Brasil). Revista da Gestão Costeira Integrada, 11, 163-169.

MEDEIROS, T. C. C., SAMPAIO, E. V. S. B. \& NASCIMENTO, D. M. 2018. Leaf area index and vegetation cover of the Paripe river mangrove, Pernambuco, Brazil, in 1997 and 2017. Journal of Integrated Coastal Zone Management, 18, 41-48.

ORTO E SILVA, E. D., PASCOALINI, S. S., ZAMPROGNO, G. C. \& TOGNELLA, M. M. P. 2020. Estimativas do teor de clorofila do mangue da Baía de Vitória (ES) por meio de dados hiperespectrais. Revista Brasileira de Geografia Física, 13, 131-142.

PARRY, C., BLONQUIST, J. \& BUGBEE, B. 2014. In situ measurement of leaf chlorophyll concentration: analysis of the optical absolute relationship. Plant, cell \& environment, 37, 2508-2520.

PASTOR-GUZMAN, J., ATKINSON, P. M., DASH, J. \& RIOJA-NETO, R. 2015. Spatiotemporal variation in mangrove chlorophyll concentration using Landsat 8. Remote Sensing, 7, 1453014558.

R CORE TEAM. 2018. R: A language and environment for statistical computing. $R$ Foudation for Statistical Computing, Vienna, Austral. Available on-line at: https:///www.R-project.org.

REBELO-MOCHEL, F. \& PONZONI, F. J. 2007. Spectral characterization of mangrove leaves in the Brazilian Amazonian Coast: Turiaçu Bay, Maranhão State. Anais da Academia Brasileira de Ciências, 79, 683-692.

RICHARDSON, A. D., DUIGAN, S. P. \& BERLYN, G. P. 2002. An evaluation of noninvasive methods to estimate foliar chlorophyll content. New phytologist, 153, 185-194.

SANTOS, H. V. S., HOLLANDA, F. S. R., SANTOS, T. O., ANDRADE, K. V. S., SANTANA, M. B. S., ESTRADA, G. C. D. \& SOARES, M. L. G. 2017. Allometric models for estimating the aboveground biomass of the mangrove Rhizophora mangle. Brazilian Journal of Oceanography, 65, 44-53.

SCHAEFFER-NOVELLI, Y., CINTRÓN-MOLERO, G., ADAIME, R. R., \& DE CAMARGO, T. M. 1990. Variability of mangrove ecosystems along the Brazilian coast. Estuaries, 13(2), 204-218.

SCHAEFFER-NOVELLI, Y., SORIANO-SIERRA, E. J., DO VALE, C. C., BERNINI, E., ROVAI, A. R., PINHEIRO, M. A. A., SCHMIDT, A. J., ALMEIDA, R., COELHO JÚNIOR, C., MENGHINI, R. P., MARTINEZ, D. I., ABUCHAHLA, G. M. O., CUNHA-LIGNON, M., CHARLIER-SARUBO, S., SHIRAZAWA-FREITAS, J. \& CINTRÓNMOLERO, G. 2016. Climate changes in mangrove forests and salt marshes. Brazilian Journal of Oceanography, 64, 37-52.

SPAROVEK, G., DE JONG VAN LIER, Q. \& DOURADO NETO, D. 2007. Computer assisted Koeppen climate classification: a case study for Brazil. International Journal of Climatology: A Journal of the Royal Meteorological Society, 27, 257-266.

VIEIRA SILVA, D., DOS ANJOS, L., BRITO-ROCHA, E., DALMOLIN, Â. C. \& MIELKE, M. S. 2016. Calibration of a multi-species model for chlorophyll estimation in seedlings of Neotropical tree species using hand-held leaf absorbance meters and spectral reflectance. iForest-Biogeosciences and Forestry, 9, 829.

ZHANG, C., LIU, Y., KOVACS, J. M., FLORES-VERDUGO, F., FLORES-DESANTIAGO, F. \& CHEN, K. 2012. Spectral response to varying levels of leaf pigments collected from a degraded mangrove forest. Journal of Applied Remote Sensing, 6, 063501. 